Clinical Research Paper

\title{
Bendamustine for the treatment of relapsed or refractory peripheral T cell Iymphomas: A French retrospective multicenter study
}

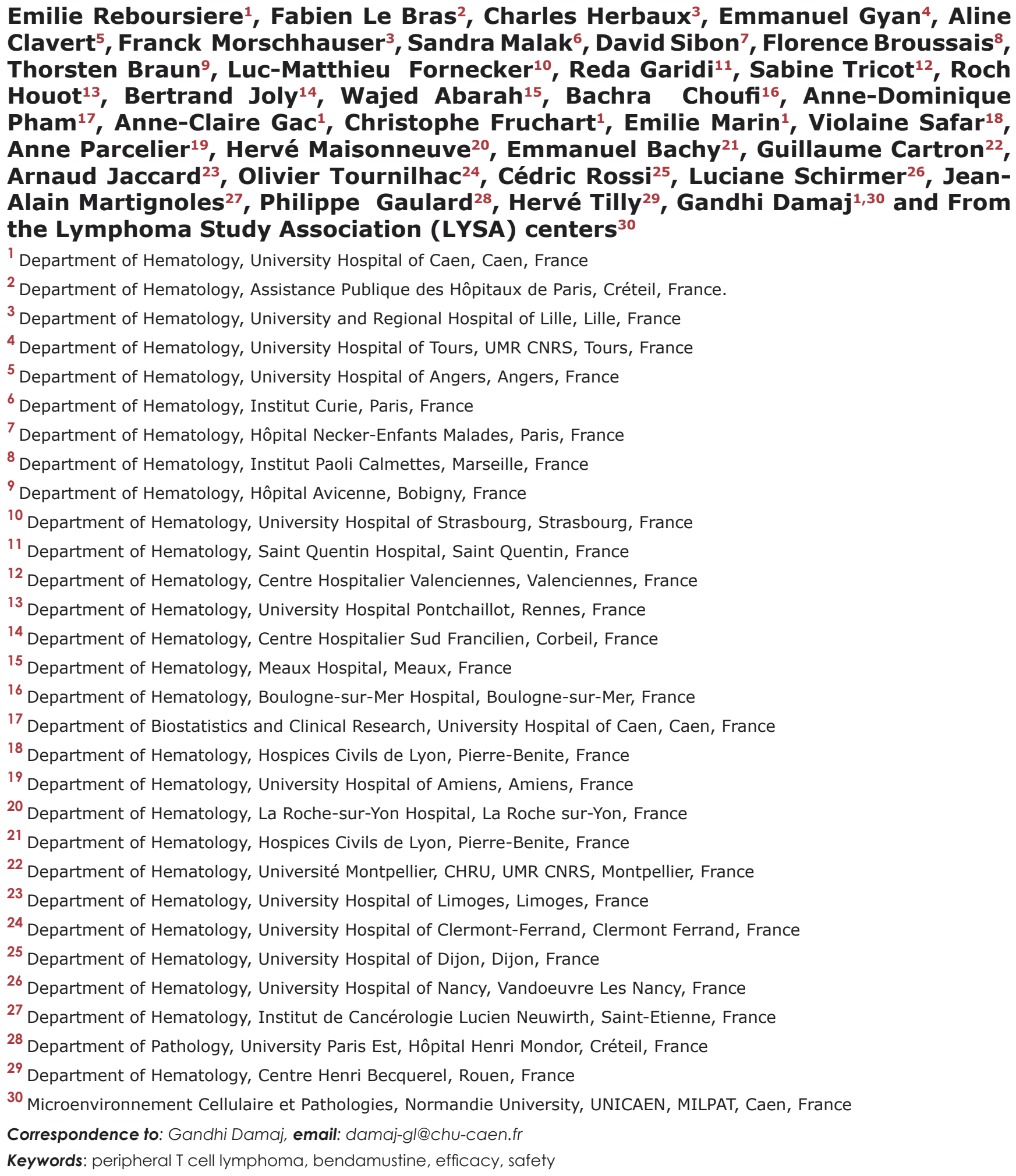




\section{ABSTRACT}

Peripheral T-cell lymphoma (PTCL) is a group of diseases with poor outcome and few therapeutic options. We aimed to assess the efficacy of bendamustine in real life cohort of patients.

Between November 2009 and March 2015, 138 PTCL patients were treated with bendamustine in 27 centers. Population median age was 64 (28-89) years with male/ female ratio of 1.4. There were mainly angio-immunoblastic (AITL = 71), PTCL-not otherwise specified (PTCL-NOS $=40$ ) and anaplastic large cell lymphoma $(A L C L=8)$. The majority of patients $(96 \%)$ had disseminated disease and extranodal localizations $(77 \%)$. Median number of chemotherapy lines prior to bendamustine was 2 (1-8). Median duration of response (DoR) after the last chemotherapy prior to bendamustine was 4.3 months (1-70) and $50 \%$ of patients had refractory disease.

Median number of administered bendamustine cycles was 2 (1-8) and 72 patients $(52 \%)$ received less than 3 mostly because of disease progression. Median dose was $90(50-150) \mathrm{mg} / \mathrm{m}^{2}$. Overall response rate (ORR) was $32.6 \%$ with complete response (CR) rate of $24.6 \%$ and median DoR was 3.3 months (1-39). AITL patients were more sensitive than PTCL-NOS patients (ORR: 45.1 versus $20 \%, p=0.01$ ). Median PFS and OS were $3.1(0.2-46.3)$ and $4.4(0.2-55.4)$ months. On multivariate analysis, refractory disease $(p=0.001)$ and extranodal localization $(p=0.028)$ adversely influenced ORR. Grade 3-4 thrombocytopenia, neutropenia and infections were reported in 22, 17 and $23 \%$ of cases respectively.

Bendamustine as single agent could be considered as a therapeutic option for relapsed or refractory PTCL, particularly in chemosensitive or AITL patients. Combinations of bendamustine with other drugs warrant further evaluation.

\section{INTRODUCTION}

Peripheral $\mathrm{T}$ cell lymphoma (PTCL) is a heterogeneous group of diseases, representing 10-15\% of lymphoma. Most PTCL have aggressive forms with poor prognosis [1-3]. Histologic subtypes influences outcome with the best prognosis is attributed to ALKpositive anaplastic-large cell lymphoma (ALCL) [4-7]. The International Prognostic Index (IPI) may be helpful in prognosticating subtypes of PTCL especially ALCL, whereas the Prognosis Index for T-cell lymphoma (PIT) is better discriminant for PTCL-NOS $[4,8]$. In the absence of more effective chemotherapy, CHOP (cyclophosphamide-anthracycline-vincristine-prednisone) regimen is the most frequent chemotherapy used in front line. Complete response (CR) rate is about $50 \%$ and 5 -year overall survival (OS) is $37 \%$ [9-13]. Autologous stem cell transplantation (ASCT) as consolidation treatment in first-line showed 5-years OS and progression-free survival (PFS) of $51 \%$ and $44 \%$, respectively [14]. Recent results of intensive chemotherapy with upfront autologous stem cell transplantation (ASCT) in eligible patients is promising $[15,16]$. Refractory disease or relapses are very frequent, concerning about $70 \%$ of patients with no standardized salvage therapy $[17,18]$. Cytarabine-based salvage regimens showed an ORR of $63 \%$ with CR of $27 \%$ and grade $3-4$ toxicities between 47 and $61 \%$ of cases
$[19,20]$. Gemcitabine, a nucleoside analog, has shown efficacy as monotherapy, in small cohort of patients, with an ORR of $55 \%$ or in combination regimens with oxaliplatin with $30 \%$ of $\mathrm{CR}$, but uncommon long-term duration of response (DoR) [21]. In a recently published series describing the population-based experience of the British Columbia Cancer Agency in 153 refractory or relapsed PTCL patients, Mak et al. have reported a median OS and PFS of 5.5 and 3.1 months respectively, with no statistically significant difference in outcome after relapse between each of the PTCL subtypes [22]. Pralatrexate, an antifolate, and romidepsin, a histone deacytelase (HDAC) inhibitor, were approved by the Food and Drug Administration for relapsed or refractory PTCL. The ORR and CR rates were 29 and $13 \%$ for pralatrexate and 25 and $15 \%$ for romidepsin. The median DoR is, however, short with only small subset of patients with long term duration of response under continuous therapy [23, 24]. Brentuximab vedotin, showed, an ORR of $86 \%$ in ALCL [25] and $41 \%$ in other PTCL subtypes with a CR rate of 24\% [26]. Consolidation with ASCT or allogeneic stem cell transplantation (HSCT) in relapse setting for fit patients is the standard of care. However, $2 / 3^{\text {rd }}$ of patients could not receive transplantation due to disease progression [18, 22, 27, 28].

Bendamustine, a bifunctionnal molecule with alkylating activity and antimetabolites properties has been 
Table 1: Patients' demographics and disease characteristics at Bendamustine

\begin{tabular}{|l|l|l|}
\hline Characteristics & N. & $\%$ \\
\hline Patients & 138 & \\
\hline Age, years & $64(27.7-88.5)$ & \\
Median (range) & 62 & 43.7 \\
\hline 65 years & & 59.4 \\
\hline Sex & 82 & 40.6 \\
Male & 56 & \\
Female & & 51.4 \\
\hline Histology & 71 & 29.0 \\
AITL & 40 & 5.8 \\
PTCL-NOS & 8 & 2.9 \\
ALCL & 4 & 6.5 \\
NKTCL & 9 & 4.4 \\
MF & 6 & \\
others & 132 & 3.6 \\
\hline Ann Arbor Stage & 5 & 96.2 \\
I-II & 127 & \\
III-IV & 135 & 25.2 \\
\hline IPI & 34 & 74.8 \\
1-2 & 101 & 77.3 \\
3-5 & $99 / 128$ & 41.9 \\
\hline Extra-nodal site involvement & $52 / 124$ & \\
\hline Bone marrow involvement & & \\
\hline Previous lines of treatment & $2(1-8)$ & 53.3 \\
Median (range) & 46 & 59.9 \\
1 & 37 & 26.8 \\
\hline 2 & & 11.5 \\
\hline Prior more & 16 & 88.4 \\
ASCT & 122 & 38.4 \\
CHOP/CHOP-like regimen & 53 & 8.0 \\
Cytarabine-based regimens & 11 & \\
Others & $12.1(1.5-108.1)$ & \\
\hline Time from diagnosis to bendamustine, months & 69 & \\
Median (range) & & \\
\hline Refractory to last prior therapy & 50.0 \\
\hline
\end{tabular}

Patients' demographics and disease characteristics at Bendamustine Abbreviations: AITL, angioimmunoblastic lymphoma; ALCL, anaplastic large-cell lymphoma; ASCT, autologous stem-cell transplantation; CHOP, cyclophosphamide, doxorubicin, vincristine, and prednisone; IPI, International Prognostic Index; MF, mycosis fungoides; NKTCL, NK/T cell lymphoma; PTCL-NOS, peripheral T cell lymphoma non other specified

shown to be effective in a large panel of hematological malignancies [29, 30]. In a recently reported phase II study, 60 patients with PTCL were treated for 6 cycles of $120 \mathrm{mg} / \mathrm{m}^{2}$ infusions of bendamustine with an ORR of $50 \%$ and complete response (CR) rates of $28 \%$ [31]. The DoR was 3.5 months with more than one third of patients with a DoR longer than 6 months. Median OS and PFS were 6.2 and 3.6 months, respectively. In a retrospective Italian cohort of 20 PTCL patients, bendamustine demonstrated an ORR of $55 \%$, CR of $10 \%$ and 6 months estimated PFS and OS of $44 \%$ and $57 \%$, respectively [32]. However, the precise place of bendamustine use among all PTCL treatment strategies is still unclear $[33,34]$.

In order to assess the efficacy of bendamustine outside clinical trials, we conducted a national retrospective study of patients with the diagnosis of PTCL and who were treated with bendamustine.

\section{RESULTS}

\section{Patient's characteristics}

From November 2009 to March 2015, 138 patients from 27 centers in France treated with bendamustine for a PTCL were analyzed (Table 1 ). The median age was 64.0 (27.7 to 88.5) years with 22 patients (16\%) older than 75 years. The male/female ratio was $1.4(83 / 59)$. Histopathologic subtypes were predominantly angioimmunoblastic T-cell lymphoma (AITL $=71,51.4 \%$ ), PTCL not otherwise specified (PTCL-NOS $=40,29.0 \%$ ), and ALCL $(n=8,5.8 \%)$. The other subtypes were rare including extranodal NK/T cell lymphoma, nasal-type $(\mathrm{ENKTCL}=4,2.9 \%)$, advanced-stage mycosis fungoide 
Table 2: Bendamustine administration schedule

\begin{tabular}{|l|l|l|}
\hline & N. & \% \\
\hline Dose & & \\
Median (range) & $90.0(40-150)$ & \\
$<90 \mathrm{mg} / \mathrm{m} 2$ & 19 & 13.7 \\
$\geq 90 \mathrm{mg} / \mathrm{m} 2$ & 119 & 86.2 \\
\hline Dose reduction & 15 & 10.8 \\
\hline Number of cycles & $2.0(1-8)$ & \\
Median (range) & 72 & 52.2 \\
$<3$ cycles & 66 & 47.8 \\
$\geq 3$ cycles & & \\
\hline
\end{tabular}

Table 3: Response to Bendamustine

\begin{tabular}{|c|c|c|c|}
\hline & $\begin{array}{l}\text { AITL } \\
N=71\end{array}$ & $\begin{array}{l}\text { PTCL-NOS } \\
N=40\end{array}$ & $\begin{array}{l}\text { Total } \\
N=138\end{array}$ \\
\hline $\begin{array}{l}\text { Overall response rate at the end of treatment } N . \\
(\%) \\
\text { ORR } \\
\text { CR } \\
\text { PR } \\
\text { Stable } \\
\text { Progressive }\end{array}$ & $\begin{array}{l}32(45.1) \\
25(35.2) \\
7(9.9) \\
0(0.0) \\
39(54.9) \\
\end{array}$ & $\begin{array}{l}8(20.0) \\
6(15.0) \\
2(5.0) \\
2(5.0) \\
32(80.0) \\
\end{array}$ & $\begin{array}{l}45(32.6) \\
34(24.6) \\
10(7.2) \\
3(2.2) \\
90(65.2) \\
\end{array}$ \\
\hline $\begin{array}{l}\text { Median time from bendamustine to response, } \\
\text { months }\left({ }_{95} \mathrm{CI}\right)\end{array}$ & $3.3(0.9-11.1)$ & $3.4(1.0-7.7)$ & $3.1(0.4-11.1)$ \\
\hline Median DoR, months $\left({ }_{05} \mathrm{CI}\right)$ & $3.3(1.0-35.5)$ & $3.2(1.0-38.8)$ & $3.3(1.0-38.8)$ \\
\hline Median OS, months $\left({ }_{95} \mathrm{CI}\right)$ & $4.5(0.2-55.4)$ & $4.4(0.7-46.3)$ & $4.4(0.2-55.4)$ \\
\hline
\end{tabular}

Abbreviations: AITL, angioimmunoblastic lymphoma; CR: complete response; DOR: Duration of response; OS: overall survival; OS: overall survival; PFS: progression free survival; PR: partial response; PTCL-NOS, peripheral T cell lymphoma non-otherwise specified.

$(\mathrm{MF}=9,6.5 \%)$, EATL $(n=2)$, subcutaneous panniculitislike-TCL $(n=1)$, hepatosplenic-TCL $(n=1)$ and unclassified PTCL $(n=2)$.

The majority of patients had disseminated-stage disease $(n=127 ; 96.2 \%)$, with extranodal localizations ( $n=99 / 128 ; 77.3 \%$ ) including bone marrow involvement ( $n=52 / 124 ; 41.9 \%$ ). The most common extranodal localizations outside bone marrow involvement were skin ( $n=17 / 138 ; 12.3 \%)$ and lung $(n=3 / 138 ; 2.2 \%)$. The IPI was high in $74.8 \%$ of patients $(n=101)$.

The median number of prior lines of chemotherapy was 2 (range 1-8) (Table 1). The most frequent prior chemotherapy used was $\mathrm{CHOP} / \mathrm{CHOP}$-like regimens in 122 patients $(88.4 \%)$ and cytarabine-based regimens in $53(38.4 \%)$ patients. Only 16 patients had autologous stem cells transplantation (ASCT $=11 \%$ ) and $7(5 \%)$ patients had allogeneic SCT prior to bendamustine. The median DoR of chemo-sensitive patients after the last chemotherapy was 4.3 months (1-70). Sixty-nine (50\%) patients had refractory disease when bendamustine treatment was initiated. Median time from diagnosis to bendamustine first infusion was 12.1 months (range 1.5-108.1). Of note, there were no significant difference for main patients' characteristics such as age, disease stage, number of previous line and disease status at bendamustine between AITL and PTCL-NOS patients at study entry (data not shown).

\section{Bendamustine administration schedule}

Bendamustine was given in all patients as monotherapy at a median dose of $90 \mathrm{mg} / \mathrm{m}^{2}$ (40-150). The dosage varied according to patients' age, previous treatments and comorbidities based on physician discretion (Table 2). Fifty-four (39.1\%) patients received $120 \mathrm{mg} /$ $\mathrm{m}^{2}$ at day 1 and 2 . Seventy-two (52.2\%) patients received fewer than 3 cycles, mainly due to disease progression $(95.8 \%, 69 / 72)$. Overall, they received a median of 2 cycles (1-8). Sixty-six (47.8\%) patients received 3 cycles or more and $30(21.7 \%)$ patients received 6 cycles.

\section{Efficacy}

The best ORR, as per the IWGC, was 32.6\% $(45 / 138)$ with a PR rate of $7.2 \%$ (10 patients), and a CR rate of $24.6 \%$ (34 patients) (Table 3 ). The median DoR was 3.3 months (1-39), 3.54 months for CR patients and 3.18 months for PR patients $(p=0.45)$. One third $(31 \%)$ of responders had durable response for more than 6 months. Six patients with PR after 3 cycles converted their response to CR after 6 cycles $(6 / 18 ; 33.3 \%)$.

Median PFS was 3.1 months (range 0.2-46.3) and median OS was 4.4 months (range 0.2-55.4) (Figure 1). Of note, 9 patients $(6.5 \%)$ received allogeneic SCT in CR.

For the $54(39.1 \%)$ patients who received the dose 

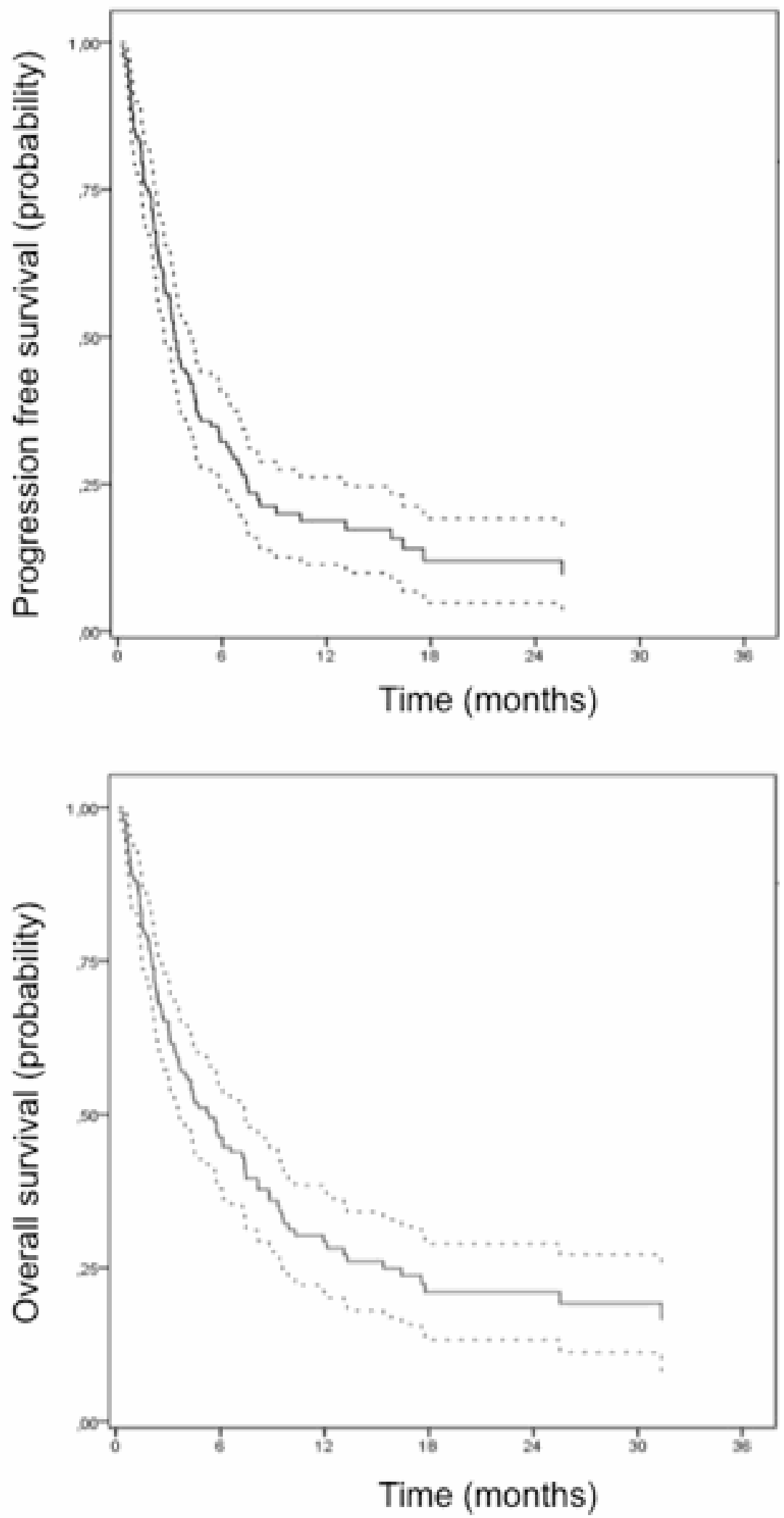

Figure 1: Progression-free survival (PFS) and Overall survival (OS) in the intent-to-treat population (n=129) 
Table 4: ORR and PFS Analysis According to Key Subsets (univariate analysis)

\begin{tabular}{|c|c|c|c|c|c|c|c|}
\hline Characteristics & $N$. & OR & $\begin{array}{l}\text { ORR* } \\
{ }_{95} \mathrm{CI}\end{array}$ & $p$ & HR & $\begin{array}{l}\text { PFS } \dagger \\
{ }_{95} \mathrm{CI}\end{array}$ & $p$ \\
\hline $\begin{array}{l}\text { Age } \\
<65 \text { years } \\
\geq 65 \text { years } \\
\end{array}$ & $\begin{array}{l}76 \\
62 \\
\end{array}$ & $\begin{array}{l}1 \\
2.75 \\
\end{array}$ & $(1.3-5.7)$ & 0.007 & $\begin{array}{l}1 \\
0.91 \\
\end{array}$ & $(0.62-1.3)$ & 0.640 \\
\hline $\begin{array}{l}\text { Sex } \\
\text { Male } \\
\text { Female }\end{array}$ & $\begin{array}{l}82 \\
56\end{array}$ & $\begin{array}{l}1 \\
2.28\end{array}$ & $(1.1-4.7)$ & 0.025 & $\begin{array}{l}1 \\
0.51\end{array}$ & $(0.34-0.8)$ & 0.001 \\
\hline $\begin{array}{l}\text { Histology } \\
\text { AITL } \\
\text { PTCL-NOS }\end{array}$ & $\begin{array}{l}71 \\
40\end{array}$ & $\begin{array}{l}1 \\
0.2\end{array}$ & $(0.1-0.5)$ & 0.010 & $\begin{array}{l}1 \\
1.69\end{array}$ & $(1.08-2.6)$ & 0.040 \\
\hline $\begin{array}{l}\text { Ann Arbor stage } \\
\text { I-II } \\
\text { III-IV }\end{array}$ & $\begin{array}{l}5 \\
127 \\
\end{array}$ & $\begin{array}{l}1 \\
2.00 \\
\end{array}$ & $(0.2-18.4)$ & 0.541 & $\begin{array}{l}1 \\
1.22 \\
\end{array}$ & $(0.49-3.0)$ & 0.663 \\
\hline $\begin{array}{l}\text { IPI } \\
1-2 \\
3-5 \\
\end{array}$ & $\begin{array}{l}34 \\
101 \\
\end{array}$ & $\begin{array}{l}1 \\
1.47 \\
\end{array}$ & $(0.6-3.5)$ & 0.381 & $\begin{array}{l}1 \\
1.47 \\
\end{array}$ & $(0.93-2.3)$ & 0.097 \\
\hline $\begin{array}{l}\text { Extra-nodal site involvement } \\
\text { No } \\
\text { Yes }\end{array}$ & $\begin{array}{l}29 \\
99\end{array}$ & $\begin{array}{l}1 \\
0.42 \\
\end{array}$ & $(0.2-0.9)$ & 0.036 & $\begin{array}{l}1 \\
1.31 \\
\end{array}$ & $(0.84-2.0)$ & 0.238 \\
\hline $\begin{array}{l}\text { Bone marrow involvement } \\
\text { No } \\
\text { Yes }\end{array}$ & $\begin{array}{l}72 \\
52\end{array}$ & $\begin{array}{l}1 \\
0.52\end{array}$ & $(0.2-1.2)$ & 0.119 & $\begin{array}{l}1 \\
1.47\end{array}$ & $(0.94-2.3)$ & 0.090 \\
\hline $\begin{array}{l}\text { Previous lines of treatment } \\
1 \\
2 \text { or }+\end{array}$ & $\begin{array}{l}46 \\
92 \\
\end{array}$ & $\begin{array}{l}1 \\
0.49\end{array}$ & $(0.2-1.0)$ & 0.059 & $\begin{array}{l}1 \\
1.68\end{array}$ & $(1.12-2.5)$ & 0.013 \\
\hline $\begin{array}{l}\text { Status at bendamustine } \\
\text { Sensitive } \\
\text { Refractory }\end{array}$ & $\begin{array}{l}69 \\
69\end{array}$ & $\begin{array}{l}1 \\
0.17\end{array}$ & $(0.1-0.4)$ & $<0.001$ & $\begin{array}{l}1 \\
1.89\end{array}$ & $(1.28-2.8)$ & 0.001 \\
\hline
\end{tabular}

Abbreviations: AILT, angioimmunoblastic lymphoma; HR, hazard ratio; IPI, International Prognostic Index; N, number of patients; OR, odds ratio; ORR, overall response rate; PFS, progression-free survival; PTCL-NOS peripheral T-cell lymphoma non other specified $*$ Logistic regression. $†$ Cox regression.

Table 5: ORR and PFS Analysis According to Key Subsets (multivariate analysis)

\begin{tabular}{|c|c|c|c|c|c|c|c|c|c|}
\hline Characteristics & $\mathbf{O R}_{\text {ajusted }}$ & $\begin{array}{l}\text { ORR } \\
{ }_{95} \mathrm{CI}\end{array}$ & $p$ & HR $_{\text {ainsted }}$ & $\begin{array}{r}\text { PFS } \\
{ }_{95} \mathrm{CI} \\
\end{array}$ & $p$ & HR $_{\text {ainsted }}$ & $\begin{array}{l}\mathrm{OS} \\
{ }_{05} \mathrm{CI}\end{array}$ & $p$ \\
\hline $\begin{array}{l}\text { IPI } \\
1-2 \\
3-5\end{array}$ & & & & $\begin{array}{l}1 \\
1.45\end{array}$ & $\begin{array}{l}(1.41- \\
3.48)\end{array}$ & 0.050 & $\begin{array}{l}1 \\
3.19\end{array}$ & $\begin{array}{l}(1.34- \\
7.59)\end{array}$ & 0.009 \\
\hline $\begin{array}{ll}\text { Extra-nodal } & \text { site } \\
\text { involvement } & \\
\text { No } & \\
\text { Yes } & \\
\end{array}$ & $\begin{array}{l}1 \\
0.2\end{array}$ & $\begin{array}{l}(0.0- \\
0.8)\end{array}$ & 0.028 & & & & & & \\
\hline $\begin{array}{lll}\text { Previous lines } & \text { of } \\
\text { treatment } & & \\
0,1 & & \\
2 \text { or }+ & & \\
\end{array}$ & & & & $\begin{array}{l}1 \\
1.77 \\
\end{array}$ & $\begin{array}{l}(1.18- \\
2.67) \\
\end{array}$ & 0.006 & $\begin{array}{l}1 \\
1.85 \\
\end{array}$ & $\begin{array}{l}(1.17- \\
2.93)\end{array}$ & 0.008 \\
\hline $\begin{array}{l}\text { Status at bendamustine } \\
\text { Sensitive } \\
\text { Refractory }\end{array}$ & $\begin{array}{l}1 \\
0.10\end{array}$ & $\begin{array}{l}(0.0- \\
0.4)\end{array}$ & 0.001 & $\begin{array}{l}1 \\
3.28\end{array}$ & $\begin{array}{l}(2.77- \\
3.79)\end{array}$ & 0.001 & $\begin{array}{l}1 \\
5.61\end{array}$ & $\begin{array}{l}(2.33- \\
13.53)\end{array}$ & $<0.001$ \\
\hline
\end{tabular}

of $120 \mathrm{mg} / \mathrm{m}^{2}$, the ORR was $37 \%(n=20 / 54)$ including $31.4 \%$ of CR $(n=17)$. The median DoR and PFS were 3.5 months and 3.9 months, respectively.

Patients older than 75 years represent $16 \%$ of the all cohort $(n=22)$ with an ORR of $50 \%$ including $37.5 \%$ of CR. The median DoR was 5.9 months (1-28.5).

Responses according to PTCL subtypes were different. ORR and CR were respectively of $45.1 \%$ (32/71) with $35.2 \%$ of CR for AITL patients, whereas it was $20.0 \%(8 / 40)$ with $15 \%$ of CR for patients with PTCL-NOS $(p=0.01)$ (Table 3-4). For AITL patients, the median DoR was 3.3 months (1-35.5) and median PFS was 3.6 months $(0.2-41.7)$ with no difference with PTCLNOS patients (Table 3 ). 

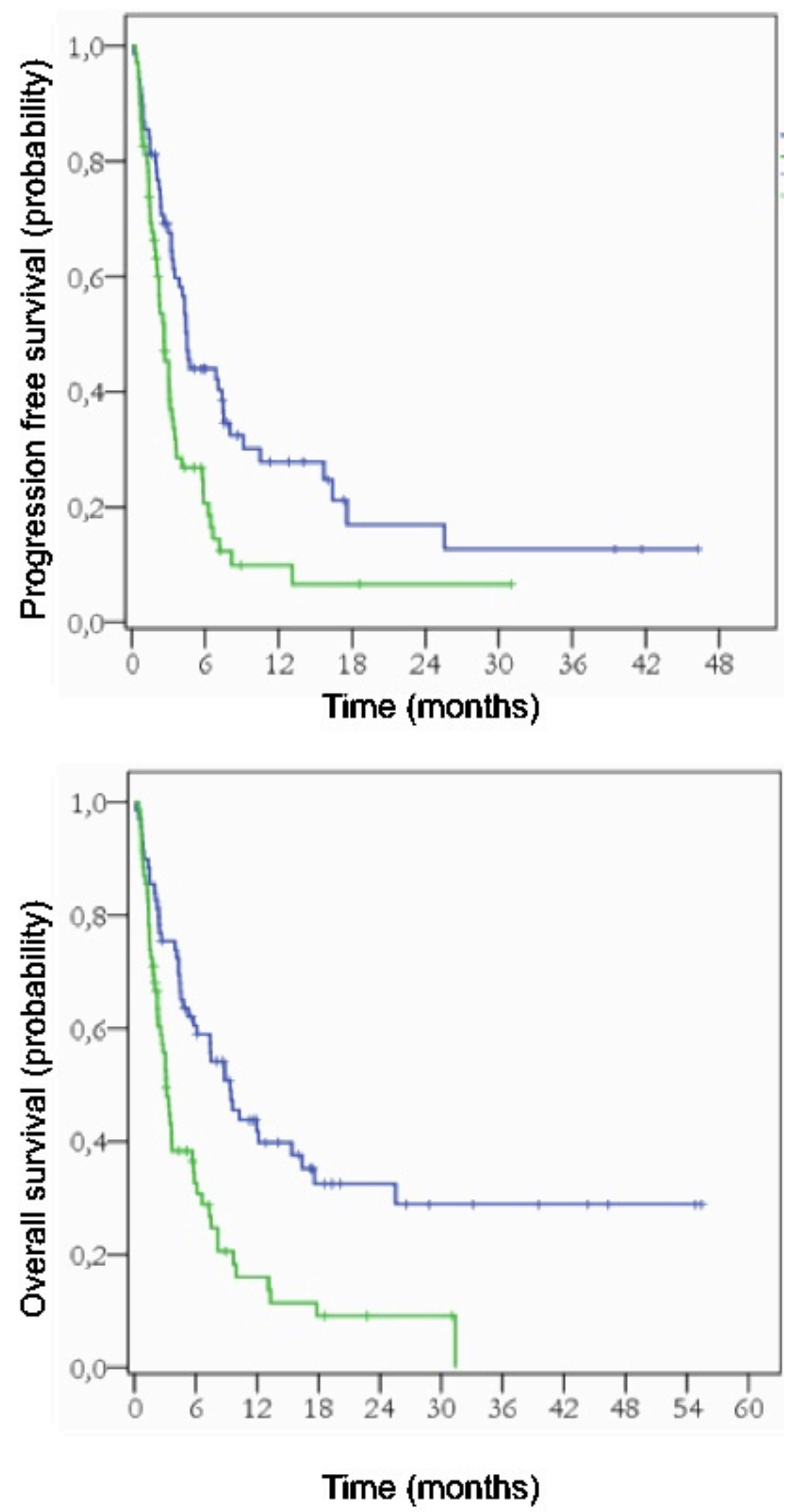

Figure 2: Progression-free survival (PFS) $(p=0.001)$ and Overall survival $(\mathrm{OS})(\mathrm{p}<0.001)$ according to chemotherapy status at the bendamustine initiation in the intent-to-treat population $(n=129)$ Blue curve: chemosensitive patients at bendamustine institution Green curve: chemo-refractory patients at bendamustine institution 
Table 6: Grade 3 to 4 adverse events in patients

\begin{tabular}{|l|l|l|}
\hline Adverse event & N. & \% \\
\hline Total events & 94 & 60.9 \\
\hline Thrombocytopenia & 31 & 22.4 \\
\hline Neutropenia & 23 & 16.7 \\
\hline Infections* & 31 & 22.5 \\
\hline Others $\dagger$ & 7 & 5.0 \\
\hline
\end{tabular}

*Infections include bacterial sepsis, septic shock, Clostridium colitis, pneumonia, Pneumocystis jiroveci pneumonia (n=1) $\dagger$ Others include cardiac arrhythmia $(n=1)$, anaphylactic shock $(n=1)$, hemolytic anemia $(n=1)$, hepatitis $(n=1)$, skin rash $(n=1)$, venous thrombosis $(n=1)$ and myelodysplasia $(n=1$; after 18 months of 8 Bendamustine courses).

\section{Prognostic factors}

In univariate analysis, ORR was affected by age ( $p=$ $0.007)$, sex $(p=0.025)$, PTCL subtype (PTCL-NOS versus AITL) $(p=0.01)$, extranodal localizations $(p=0.036)$ and disease status (refractory versus relapsed) at bendamustine $(p<0.001)$ (Table 4).

In multivariate analysis, disease status [OR 0.1 ; $\mathrm{CI}(0.0-0.4) ; p=0.001]$ and extranodal disease [OR $0.2 ; \mathrm{CI}(0.0-0.8) ; p=0.028]$ at bendamustine initiation remained the only factors that negatively influenced the ORR (Table 5).

Overall survival was negatively impacted by the number of previous chemotherapy lines [HR 1.85; $\mathrm{CI}(1.17-2.93) ; p=0.008]$, disease status at bendamustine [HR 5.61; CI(2.33-13.53); $p<0.001]$ and IPI [HR 3.19; CI(1.34-7.59); $p=0.009]$. In the same way, the number of prior treatment [HR 1.77; CI(1.18-2.67); $p=0.006]$, disease status [HR 3.28; CI(2.77-3.79); $p=0.001]$ and IPI [HR 3.13; CI(1.41-6.96); $p=0.005]$ influenced PFS (Table 5 and Figure 2).

\section{Safety}

After a median follow up 4.4 months, $72 \%$ of patients (99/138) died. The causes of death were: disease progression $(93.9 \%, n=94)$ or toxicities $(5.0 \%$, $n=5$ ). Grade $3 / 4$ thrombocytopenia, neutropenia and infections occurred in $22.4 \%, 16.7 \%$ and $22.5 \%$ of cases, respectively (Table 6). The main grade $3-4$ infections included bacterial sepsis, septic shock, Clostridium colitis and pneumonia. The five toxic deaths were secondary to septic shock with clostridium colitis $(n=1)$, pneumonia with pseudomonas aeruginosa $(n=1)$, toxicity related mortality post allogeneic stem cell transplantation $(n=2)$ and pneumocystis jiroveci pneumonia $(n=1)$.

\section{DISCUSSION}

This retrospective study confirms the efficacy of bendamustine in a large cohort of PTCL patients treated outside clinical trials with a CR rate of $24.6 \%$. These results are concordant with the two prior studies, the prospective BENTLY trial [31] and the retrospective Italian study [32]. However, the ORR (32.6\%) and $\mathrm{PR}$ rate $(7.2 \%)$ rate are lower in this cohort than in the prospective BENTLY study $(\mathrm{ORR}=50 \%$; $\mathrm{PR}=26 \%)$. In this study, patients were more intensely treated before bendamustine with an increased number of patients with more than 2 lines of previous chemotherapy, lower dose $\left(90 \mathrm{mg} / \mathrm{m}^{2}\right)$ and less cycles of bendamustine than in the BENTLY study. The low percentage of partial responders as compared to the previous studies is difficult to explain. However, we could hypothesize that lower stringent criteria were applied to stop the treatment in this cohort of highly aggressive disease than in a prospective study. We emphasize that one third of patients in PR after 3 cycles converted their response to $\mathrm{CR}$ at 6 cycles, which may indicate an advantage to pursue the treatment if any response is reached.

Patients' other characteristics in this cohort are similar to those reported in the two previous ones regarding age, sex ratio and disease stage. However, the high frequency of AITL in the current cohort is in keeping with the recent report of the high prevalence of AITL in France [35].

This study can be helpful to predict patients who are more likely to respond to bendamustine. Patients with AITL were more sensitive to this drug than patients with other pathological subtypes (univariate analyses) as has been suggested previously [31]. We found a good prognosis impact of having chemosensitive disease status without extranodal localization on response and outcome. We showed also an improved outcome if patients had lower than 3 prior therapies lines or IPI lower than 3 (multivariate analysis).

Bendamustine is effective and safe, even in elderly patients, older than 75 years. ORR and CR rates were not different from those of younger patients. This efficacy and the toxicity profiles of the drug could suggest its preferential use in this group of patients aged more than 70 years old. Furthermore, it could be used as a bridge to transplant in younger patients.

In conclusion, bendamustine may represent an alternative therapy for relapsed or refractory PTCL patients in real-life settings and could be considered as 
a salvage strategy. These results could be helpful to select patients who will be more likely to respond to bendamustine. Having chemosensitive disease at relapse after being treated with less than 3 lines of chemotherapy are predictive factors for response. The DoR is unfortunately short as with other multiple single agent treatment suggesting the need for evaluating combination drugs in prospective trials.

\section{MATERIALS AND METHODS}

Hematological French centers were asked to report retrospectively the results of the use of bendamustine in refractory or relapsed PTCL patients. Patients aged 18 years old or more with the diagnosis of PTCL were included. Primary cutaneous T cell lymphoma with a stage less than IIB [36], Sezary syndrome, the leukemic forms according to the WHO classification [3] and patients who received bendamustine in the BENTLY trial [31] were excluded from the analysis. Patients' demographics and clinical characteristics, histologic subtypes, prior therapies, disease status, bendamustine dosage and schedule were reported. Pathological review through Lymphopath was available for 80 (58\%) patients [35]. Responses were evaluated according to the International Working group criteria (IWGC) [37] and International Society for Cutaneous Lymphomas/ European Organization for Research and Treatment of Cancer (ISCL/EORTC) revision classification [36]. Toxicities were assessed according to the adverse events recording using the National Cancer Institute's Common terminology Criteria for Adverse Events (NCI CTCAE) version 4. PFS and OS distribution were calculated using Kaplan-Meier estimates. Patients who underwent allogeneic stem cell transplant after bendamustine treatment were excluded from the analyses of the DoR, OS and PFS. PTCL-NOS and AITL comparison was assessed by Chi-2 or Fisher's exact tests for qualitative variable and Mann-Whitney test for quantitative variable. Predictive variables for ORR were determined by using uni- and multivariate logistic regression. Results were expressed as odds ratios and confidence intervals $\left({ }_{95} \mathrm{CI}\right)$. For OS and PFS, we used the Cox proportional hazards models with a stepwise backward variable selection approach $(\mathrm{p} \leq 0.20)$ for multivariate analysis and to obtain hazard ratios with confidence intervals. All reported $\mathrm{p}$ values were two-sided, and the significance limit was set at 5\%.

\section{ACKNOWLEDGMENTS}

The authors thank all the participants who helped to collect data: Catherine Ollivier and Alexandra Hebert (CHU Caen).

\section{CONFLICTS OF INTERESTS}

Gandhi Damaj and Guillaume Cartron received unrestricted research grant from Mundipharma. Emmanuel Gyan is coordinating investigator for a clinical study supported by Mundipharma.

\section{FUNDING}

This work had no specific funding.

\section{REFERENCES}

1. Foss FM, Zinzani PL, Vose JM, Gascoyne RD, Rosen ST, Tobinai K. Peripheral T-cell lymphoma. Blood 2011; 117:6756-6767.

2. Armitage JO, Vose JM, Weisenburger DD. Towards understanding the peripheral T-cell lymphomas. Ann. Oncol. Off. J. Eur. Soc. Med. Oncol. Esmo 2004; 15:14471449.

3. Swerdlow S, Campo E, Harris NL, Jaffe ES, Pileri SA, Stein H, Thiele J, Vardiman JW. WHO Classification of Tumours of Haematopoietic and Lymphoid Tissue, 4th edition. Lyon: International Agency for Research on Cancer, 2008.

4. Vose J, Armitage J, Weisenburger D. International T-Cell Lymphoma Project. International peripheral T-cell and natural killer/T-cell lymphoma study: pathology findings and clinical outcomes. J. Clin. Oncol. Off. J. Am. Soc. Clin. Oncol. 2008; 26:4124-4130.

5. Gisselbrecht C, Gaulard P, Lepage E, Coiffier B, Brière J, Haioun C, Cazals-Hatem D, Bosly A, Xerri L, Tilly H, Berger F, Bouhabdallah R, Diebold J. Prognostic Significance of T-Cell Phenotype in Aggressive NonHodgkin's Lymphomas. Blood 1998; 92:76-82.

6. Savage KJ, Chhanabhai M, Gascoyne RD, Connors JM. Characterization of peripheral T-cell lymphomas in a single North American institution by the WHO classification. Ann. Oncol. Off. J. Eur. Soc. Med. Oncol. Esmo 2004; 15:14671475 .

7. Tilly H, Gaulard P, Lepage E, Dumontet C, Diebold J, Plantier I, Berger F, Symann M, Petrella T, Lederlin P, Brière J. Primary anaplastic large-cell lymphoma in adults: clinical presentation, immunophenotype, and outcome. Blood 1997; 90:3727-3734.

8. Gutiérrez-García G, García-Herrera A, Cardesa T, Martinez A, Villamor N, Ghita G, Martinez-Trillos A, Colomo L, Setoain X, Rodriguez S, Giné E, Campo E, LopezGuillermo A. Comparison of four prognostic scores in peripheral T-cell lymphoma. Ann. Oncol. Off. J. Eur. Soc. Med. Oncol. Esmo 2011; 22:397-404.

9. Abouyabis AN, Shenoy PJ, Lechowicz MJ, Flowers CR. Incidence and outcomes of the peripheral T-cell lymphoma subtypes in the United States. Leuk. Lymphoma 2008; 49:2099-2107. 
10. Fisher RI, Gaynor ER, Dahlberg S, Oken MM, Grogan TM, Mize EM, Glick JH, Coltman CA, Miller TP. Comparison of a standard regimen (CHOP) with three intensive chemotherapy regimens for advanced non-Hodgkin's lymphoma. N. Engl. J. Med. 1993; 328:1002-1006.

11. Briski R, Feldman AL, Bailey NG, Lim MS, Ristow K, Habermann TM, Macon WR, Inwards DJ, Colgan JP, Nowakowski GS, Kaminski MS, Witzig TE, Ansell SM et al. The role of front-line anthracycline-containing chemotherapy regimens in peripheral T-cell lymphomas. Blood Cancer J. 2014; 4:e214.

12. Schmitz N, Trümper L, Ziepert $M$, Nickelsen $M$, Ho AD, Metzner B, Peter N, Loeffler M, Rosenwald A, Pfreundschuh M. Treatment and prognosis of mature T-cell and NK-cell lymphoma: an analysis of patients with T-cell lymphoma treated in studies of the German High-Grade Non-Hodgkin Lymphoma Study Group. Blood 2010; 116:3418-3425.

13. Simon, A. Upfront VIP-reinforced-ABVD (VIP-rABVD) is not superior to $\mathrm{CHOP} / 21$ in newly diagnosed peripheral $\mathrm{T}$ cell lymphoma. Results of the randomized phase III trial GOELAMS-LTP95. .

14. D' Amore F, Relander T, Lauritzsen GF, Jantunen E, Hagberg H, Anderson H, Holte H, Österborg A, Merup M, Brown P, Kuittinen O, Erlanson M, Ostenstad B et al. Up-front autologous stem-cell transplantation in peripheral T-cell lymphoma: NLG-T-01. J. Clin. Oncol. Off. J. Am. Soc. Clin. Oncol. 2012; 30:3093-3099.

15. Reimer $\mathrm{P}$, Rüdiger $\mathrm{T}$, Geissinger $\mathrm{E}$, Weissinger $\mathrm{F}$, Nerl C, Schmitz N, Engert A, Einsele H, Müller-Hermelink H, Wilhelm M. Autologous stem-cell transplantation as firstline therapy in peripheral T-cell lymphomas: results of a prospective multicenter study. J. Clin. Oncol. Off. J. Am. Soc. Clin. Oncol. 2009; 27:106-113.

16. Ellin F, Landström J, Jerkeman M, Relander T. Real-world data on prognostic factors and treatment in peripheral T-cell lymphomas: a study from the Swedish Lymphoma Registry. Blood 2014; 124:1570-1577.

17. Corradini P, Marchetti M, Barosi G, Billio A, Gallamini A, Pileri S, Pimpinelli N, Rossi G, Zinzani PL, Tura S. SIE-SIES-GITMO guidelines for the management of adult peripheral T- and NK-cell lymphomas, excluding mature T-cell leukaemias. Ann. Oncol. Off. J. Eur. Soc. Med. Oncol. Esmo 2014; 25:2339-2350.

18. Dreyling $\mathrm{M}$, Thieblemont $\mathrm{C}$, Gallamini A, Arcaini L, Campo E, Hermine O, Kluin-Nelemans JC, Ladetto M, Le Gouill S, Iannitto E, Pileri S, Rodriguez J, Schmitz N et al. ESMO Consensus conferences: guidelines on malignant lymphoma. part 2: marginal zone lymphoma, mantle cell lymphoma, peripheral T-cell lymphoma. Ann. Oncol. 2013; 24:857-877.

19. Puig N, Wang L, Seshadri T, al-Farsi K, Keating A, Crump M, Kuruvilla J. Treatment response and overall outcome of patients with relapsed and refractory peripheral T-cell lymphoma compared to diffuse large B-cell lymphoma.
Leuk. Lymphoma 2013; 54:507-513.

20. Mercadal S, Briones J, Xicoy B, Pedro C, Escoda L, Estany C, Camos M, Colomo L, Espinosa I, Martinez S, Ribera JM, Martino R, Gutiérrez-Garcia G et al. Intensive chemotherapy (high-dose CHOP/ESHAP regimen) followed by autologous stem-cell transplantation in previously untreated patients with peripheral T-cell lymphoma. Ann. Oncol. Off. J. Eur. Soc. Med. Oncol. Esmo 2008; 19:958963.

21. Zinzani PL, Venturini F, Stefoni V, Fina M, Pellegrini C, Derenzini E, Gandolfi L, Broccoli A, Argnani L, Quirini F, Pileri S, Baccarani M. Gemcitabine as single agent in pretreated T-cell lymphoma patients: evaluation of the longterm outcome. Ann. Oncol. Off. J. Eur. Soc. Med. Oncol. Esmo 2010; 21:860-863.

22. Mak V, Hamm J, Chhanabhai M, Shenkier T, Klasa R, Sehn L, Villa D, Gascoyne RD, Connors JM, Savage KJ. Survival of Patients With Peripheral T-Cell Lymphoma After First Relapse or Progression: Spectrum of Disease and Rare Long-Term Survivors. J. Clin. Oncol. 2013; 31:19701976.

23. O'Connor OA, Pro B, Pinter-Brown L, Barlett N, Popplewell L, Coiffier B, Lechowicz MJ, Savage KJ, Shustov AR, Gisselbrecht C, Jacobsen E, Zinzani PL, Furman $\mathrm{R}$ et al. Pralatrexate in patients with relapsed or refractory peripheral T-cell lymphoma: results from the pivotal PROPEL study. J. Clin. Oncol. Off. J. Am. Soc. Clin. Oncol. 2011; 29:1182-1189.

24. Piekarz RL, Frye R, Prince HM, Kirschbaum MH, Zain J, Allen SL, Jaffe ES, Ling A, Turner M, Peer CJ, Figg WD, Steinberg SM, Smith S et al. Phase 2 trial of romidepsin in patients with peripheral T-cell lymphoma. Blood 2011; 117:5827-5834.

25. Pro B, Advani R, Brice P, Bartlett NL, Rosenblatt JD, Illidge T, Matous J, Ramchandren R, Fanale M, Connors JM, Yang Y, Sievers EL, Kennedy DA et al. Brentuximab Vedotin (SGN-35) in Patients With Relapsed or Refractory Systemic Anaplastic Large-Cell Lymphoma: Results of a Phase II Study. J. Clin. Oncol. 2012; 30:2190-2196.

26. Horwitz SM, Advani RH, Bartlett NL, Jacobsen ED, Sharman JP, O'Connor OA, Siddiqi T, Kennedy DA, Oki Y. Objective responses in relapsed T-cell lymphomas with single-agent brentuximab vedotin. Blood 2014; 123:30953100 .

27. Nickelsen M, Ziepert M, Zeynalova S, Glass B, Metzner B, Leithaeuser M, Mueller-Hermelink HK, Pfreundschuh M, Schmitz N. High-dose CHOP plus etoposide (MegaCHOEP) in T-cell lymphoma: a comparative analysis of patients treated within trials of the German High-Grade Non-Hodgkin Lymphoma Study Group (DSHNHL). Ann. Oncol. Off. J. Eur. Soc. Med. Oncol. Esmo 2009; 20:19771984.

28. Le Gouill S, Milpied N, Buzyn A, Peffault De Latour R, Vernant JP, Mohty M, Moles MP, Bouabdallah Krimo, Bulabois CE, Dupuis J, Rio B, Gratecos N, Yakoub-Agha 
I et al. Graft-versus-lymphoma effect for aggressive T-cell lymphomas in adults: a study by the Société Francaise de Greffe de Moëlle et de Thérapie Cellulaire. J. Clin. Oncol. Off. J. Am. Soc. Clin. Oncol. 2008; 26:2264-2271.

29. Derenzini E, Zinzani PL, Cheson BD. Bendamustine: role and evidence in lymphoma therapy, an overview. Leuk. Lymphoma 2014; 55:1471-1478.

30. Cheson BD, Rummel MJ. Bendamustine: rebirth of an old drug. J. Clin. Oncol. Off. J. Am. Soc. Clin. Oncol. 2009; 27:1492-1501.

31. Damaj G, Gressin R, Bouabdallah K, Cartron G, Choufi B, Gyan E, Banos A, Jaccard A, Park S, Tournilhac O, Schiano-de Collela, J, Voillat L, Joly B et al. Results from a prospective, open-label, phase II trial of bendamustine in refractory or relapsed T-cell lymphomas: the BENTLY trial. J. Clin. Oncol. Off. J. Am. Soc. Clin. Oncol. 2013; 31:104-110.

32. Zaja F, Baldini L, Ferreri AJM, Luminari S, Grossi A, Salvi F, Zambello R, Goldaniga M, Volpetti S, Fanin R. Bendamustine salvage therapy for $\mathrm{T}$ cell neoplasms. Ann. Hematol. 2013; 92:1249-1254.

33. Moskowitz AJ, Lunning MA, Horwitz SM. How I treat the peripheral T-cell lymphomas. Blood 2014; 123:2636-2644.

34. Coiffier B, Federico M, Caballero D, Dearden C, Morschhauser F, Jäger U, Trümper L, Zucca E, Gomes da Silva M, Pettengell R, Weidmann E, d'Amore F, Tilly H et al. Therapeutic options in relapsed or refractory peripheral T-cell lymphoma. Cancer Treat. Rev. 2014; 40:1080-1088.
35. De Leval L, Parrens M, Le Bras F, Jais JP, Fataccioli V, Martin A, Lamant L, Delarue R, Berger F, Arbion F, Bossard C, Copin MC, Canioni D et al. Angioimmunoblastic $\mathrm{t}$-cell lymphoma is the most common t-cell lymphoma in two distinct french information data sets. Haematologica 2015 Sep;100:361-4.

36. Olsen E, Vonderheid E, Pimpinelli N, Willemze R, Kim Y, Knobler R, Zackheim H, Duvic M, Estrach T, Lamberg S, Wood G, Dummer R, Ranki A et al. Revisions to the staging and classification of mycosis fungoides and Sezary syndrome: a proposal of the International Society for Cutaneous Lymphomas (ISCL) and the cutaneous lymphoma task force of the European Organization of Research and Treatment of Cancer (EORTC). Blood 2007; 110:1713-1722.

37. Cheson BD, Horning SJ, Coiffier B, Shipp MA, Fisher RI, Connors JM, Lister TA, Vose J, Grillo-Lopez A, Hagenbeek A, Cabanillas F, Klippensten D, Hiddemann W et al. Report of an international workshop to standardize response criteria for non-Hodgkin's lymphomas. NCI Sponsored International Working Group. J. Clin. Oncol. Off. J. Am. Soc. Clin. Oncol. 1999; 17:1244. 